\title{
A Framework of IS/Business Alignment Management Practices to Improve the Design of IT Governance Architectures
}

\author{
Jorge Orozco ${ }^{1}$, Ali Tarhini ${ }^{1}$, Ra'ed (Moh'd Taisir) Masa'deh ${ }^{2} \&$ Takwa Tarhini ${ }^{3}$ \\ ${ }^{1}$ Department of Computer Science, Brunel University, London, United Kingdom \\ ${ }^{2}$ Department of Management Information Systems, The University of Jordan, Jordan \\ ${ }^{3}$ Department of Electrical and Computer Engineering, Texas A\&M University, Qatar \\ Correspondence: Ali Tarhini, Department of Computer Science, Brunel University, London, United Kingdom. \\ E-mail: ali.tarhini@brunel.ac.uk
}

Received: January 16, 2015

Accepted: February 11, 2015

Online Published: March 27, 2015

doi:10.5539/ijbm.v10n4p1

URL: http://dx.doi.org/10.5539/ijbm.v10n4p1

\begin{abstract}
This research aims to identify specific management practices that can help to improve the process of IS/business alignment and the design of ITG architecture that supports those processes. To this end the authors propose a framework that is used as a reference to classify relevant management practices in the process of IS/business alignment and design of ITG architectures. The analysis was carried out in a large leading international food and beverage company. Findings show that at operational and tactical levels, improving the coordination of the IT investment management process and enabling structures that strengthen the connection of budgetary controls are core structural capabilities that can positively improve the process of IS/business alignment and impact significantly the design of ITG architectures.
\end{abstract}

Keywords: IT/IS management, IS planning, IS/business alignment, strategic alignment, alignment assessment

\section{Introduction}

IS/Business alignment is seen as a necessary management practice that can enable information systems (IS) to adapt to the changing business environment (Tarhini et al., 2015a,b; Abbasi et al., 2015). Over more than two decades, practitioners and academics have continuously demonstrated interest on IS/business alignment and ranked it as a top management need. However, solutions to achieve IS/business alignment are still vague due to its complexity and holistic understanding. Despite this fact, several business benefits appear as the main justification to support its implementation. Empirical studies demonstrate that the alignment in organizations help to enhance organizational performance (Teo \& King, 1996; Chan, Sabherwal, \& Thatcher, 2006; Masa'deh \& Kuk, 2009; Yayla \& Hu, 2012; Walter et al., 2013; Wagner, 2014) and enables IT/business value (Melville, Kraemer, \& Gurbaxani, 2004; Shannak et al., 2010; Chiang \& Nunez, 2013; Siurdyban, 2014). Considering these organizational benefits, there is imminent and recurrent question that practitioners aim to answer: what do organizations need to positively advance the process of IS/business alignment? Despite several efforts to answer this question, there is still perennial work to contribute into the IS/business alignment research agenda. Literature in IS/business alignment is diverse, well-supported and ongoing research still is looking to establish its relevance in the context of IS use. Different approaches, dimensions and paradigms have characterized its progress (Chan \& Reich, 2007; Gutierrez et al., 2009; Masa'deh et al., 2014). In the way to better understand IS/business alignment, literature has provided rich but theoretical research that lacks of pragmatic approaches. Particularly, few attempts advance pragmatically on the process of assessing, maintaining or sustaining IS/business alignment (Avison et al., 2004; Chan \& Reich, 2007; Masa'deh \& Shannak, 2012) and even fewer studies specify punctual management capabilities towards the consolidation of an IS/business alignment process (Luftman, 2004).

IT Governance (ITG) is a more recent area of research with approximately a decade of age. Despite ITG has been defined in different ways; most definitions stress how management needs to make decisions rather than what decisions to be made. It could be argued that ITG has an older history as it has been considered within corporate governance research; however the current IT-driving era supports the ITG's own personality. ITG, as area of research, has evolved over the past years from an IT-oriented into a more business-oriented practice. The implementations of ITG have gained relevance either to promote efficient organizational IT performance 
(Simonsson, Johnson, \& Ekstedt, 2010; Wraikat, 2012; Curry et al., 2014, Alenezi et al., 2015; Tarhini et al., $2015 \mathrm{c}$ ) or accomplish legal regulations (ISO/IEO, 2014). Researches have agreed that ITG is a control-based system that includes internal and external management practices that enable and impact IS/business alignment (Peterson, 2004). According to Peterson (2004) and Weill and Ross (2004), ITG mechanisms or capabilities should be divided into three sets [process, relations, structures] in order to understand their scope and effect. The setting up of such mechanisms or capabilities constitutes a baseline to support making-decision processes and make valid organizational rules and procedures. Only then, the resulted ITG architecture can enable the IS/business alignment process and enhance organizational IT/business value.

Researchers and practitioners have identified tight relationships between ITG, IS/business alignment and business value (De Haes \& Van Grembergen, 2009; Buchwald, Urbach, \& Ahlemann, 2014). However there are few studies that link those studies to identify their relationships. This research aims to identify those management practices that can positively moderate and improve the process of IS/business alignment and the design of ITG. In order to identify these management practices, the management capabilities from the strategic alignment maturity (SAM) model proposed by Luftman (2000) were mapped against the structure of the ITG assessment process (ITGAP) model defined by Peterson (2004). The resulted mapping framework was used as a reference to classify management practices and analyze relevant management practices in the process of IS/business alignment and design of ITG architectures. The analysis was carried out colleting management practices from a leading and large food and beverage company. Findings show that at operational and tactical levels, improving the coordination of the IT investment management process and enabling structures that strengthen the connection of budgetary controls are core structural capabilities that can positively improve and moderate the process of IS/business alignment and impact significantly the design of ITG. By promoting program management practices towards a unified understanding of IT and business knowledge, the collaboration between strategic and operational levels would be positively influenced.

This paper is divided in five sections. The following section outlines the research in IS/business alignment and its links with ITG. In section three, both SAMM and ITGAP are discussed and the proposed framework is introduced. Section four includes the case study analysis. In the last section, the results and conclusions are presented.

\section{IT Governance and IS/Business Alignment Antecedents}

IS/business alignment has been researched as a phenomenon that focuses on the complexity of organizational relationships given by the integration of IT and business strategies (Broadbent \& Weill, 1993; Henderson \& Venkatraman, 1993; Ciborra, 1997, Smaczny, 2001), plans (Kearns \& Lederer, 2000; Reich \& Benbasat, 2000; Cragg, King, \& Hussin, 2002; Balocco, Ciappini, \& Rangone, 2013), or structures (Weill, \& Ross, 2004). In more than two decades, these different approaches have revealed several loci research in IS/business alignment (Chan \& Reich, 2007; Coltman, Sharma, \& Tallon, 2013; Tarhini et al., 2015d) and also contributed marginally subscribing its broad and complex understanding. A specific challenge that IS/business alignment research agenda faces is its holistic scope. To conceptualize IS/business alignment, several dimensions have been indicated to portray its understanding. Four dimensions have been commonly referenced and cited: strategic or intellectual (Kearns \& Lederer, 2000), operational (Papp \& Luftman, 1995; Chan, 2002), informal structural (Chan, 2001; Chan, Sabherwal, \& Thatcher, 2006) and cultural (Pyburn, 1983). These dimensions have been traditionally isolated approaches to understand and approach IS/business alignment research. However, a new organic and co-evolutional view suggests integrating these IS/business alignment dimensions in order to consolidate new IS/business alignment theory foundations. Benbya and McKelvey (2006) propose that IS/business alignment is the result of a series of adjustments at three levels of analysis: individual, operational and strategic. Most important in this view, they justify causal dynamics rather than cause-effect logic of managerial actions to impact all organizational levels and their performance. Empirically, the business characteristics of ITG have been a justification to consider their implementations as an alternative to develop such managerial actions along organizations. For instance, the adoption of frameworks such as COBIT, ITIL or ISO/IEC 38500-2008 exemplifies the relevance of different mechanisms to enhance an organizational platform to achieve tight IS/business alignment and higher IS/business value.

\subsection{Linking IS/Business Alignment and IT Governance}

Literature has shown that similar outcomes can result of either achieving IS/business alignment or implementing ITG practices. Empirical studies evidence that higher organizational performance can be the result of tight IS/business alignment (Kearns \& Lederer, 2003; Masa'deh \& Kuk, 2009) but also consequence of effective implementations of ITG practices (Weill \& Ross, 2004; Tallon et al., 2013). Both IS/business alignment and ITG 
areas have been researched independently and few studies indicate mechanisms that link their consequences or antecedents (Chaudhuri, 2011; Buchwald et al., 2014; Thompson et al., 2014). For instance, literature disagrees to show how both areas are related. The IT Governance Institute (ITGI) considers IS/business alignment as one out of five areas of concern within ITG [strategic alignment, value delivery, risk management, resource management and performance management]. Conversely, SAM includes ITG as one out of six IS/business alignment maturity factors [communication, value measurement, IT governance, partnership, scope \& architecture and skills] to assess IS/business alignment maturity. Researchers have called for studies that look for those relationships between IT/business value, IS/business alignment and ITG but have anticipated that ITG is an antecedent and enabler for achieving IS/business (De Haes \& Van Grembergen, 2010; Schlosser et al., 2010; Wagner, Beimborn, \& Weitzel, 2014). The implementation of ITG practices builds up a baseline that should include processes, structures and relational capabilities. These managerial abilities enable people to execute their responsibilities in support of IS/business alignment and the creation of IT/business value (Peterson, 2004). To achieve higher organizational performance, those capabilities need to be identified and then amalgamate an enterprise management system that facilitates controls along different information systems (Peterson, 2004; Beimborn, Schlosser, \& Weitzel, 2009; Tiwana, 2012; Wagner \& Weitzel, 2012; Zolper, Beimborn, \& Weitzel, 2014).

The authors of this paper coincide with the notion that the relationship between IS/business alignment and ITG is important but additional research will clarify their relationships. The relationships between IS/business alignment and ITG and the identification of their common management practices would help to focus efforts on specific managerial actions and impact organizational performance significantly. In the literature, the identification of these practices has been rarely discussed.

\section{Assessment Framework Overview}

\subsection{The Role of Management Practices in IS/Business Alignment and ITG}

Managing IT also means meeting business objectives while targeting strategic, tactical and operational levels and handling a complex number of organizational assets and factors (Gutierrez et al., 2008; Gutierrez, Orozco, \& Serrano, 2009). Benbya and McKelvey (2006) have considered theoretically the co-evolutionary dynamics of these organizational levels as a function of IS/business alignment. They propose an emergent nature that underpins IS/business alignment "as a continuous coevolutionary process that reconciles top-down 'rational design' and bottom-up 'emergent process' of consciously and coherently interrelating all components of the IS/business alignment at three levels of analysis [strategic, operational and individual]". This contemporary view innovates the integration of different alignment dimensions to consolidate a new IS/business alignment theory. For instance, the operational level of analysis includes social and structural or operational components. The dynamics at this level offers insights into how ITG mechanisms influence business process performance (Beimborn, Schlosser, \& Weitzel, 2009). In addition, decision-making processes and relationships of stakeholders also contribute in such dynamics. However, operational performance also depends on structures and capabilities to establish making-decision mechanisms (Hirschheim \& Sabherwal, 2001). To this end, decisions to develop what capabilities to implement and how they should be arranged are the result of strategic management decisions to realize IS/business value (Weill \& Ross, 2004).

ITG has been conceptualized as "the distribution of IT decision-making rights and responsibilities among different stakeholders in the enterprise, and defines the procedures and mechanisms of making and monitoring strategic IT decisions" (Peterson, O'Callaghan, \& Ribbers, 2000). In this notion, managerial abilities play an important organizational role to coordinate activities related to IT plans, organization and controls. Peterson (2004) groups them in three sets according to their key mechanisms and also calls them capabilities. Each set embraces lateral structures, processes and relational capabilities. Process capability refers to the coordination of strategic IT monitoring and IT decision-making process. Relational capability comprises the collaboration of active business and IT partnership and shared learning. Structural capability involves the connection of formal mechanisms such as positions, roles and organizational structures to build liaisons between IT and business (see Table 1). 
Table 1. Summary of IT governance capabilities (adapted from Peterson et al., 2000)

\begin{tabular}{|c|c|c|c|}
\hline Strategies & Structures & Processes & $\begin{array}{l}\text { Relational } \\
\text { (Structures and processes) }\end{array}$ \\
\hline Tactics & $\begin{array}{l}\text {-Positions and roles } \\
\text {-Organizational structures }\end{array}$ & $\begin{array}{l}\text {-Strategic IT decision-making } \\
\text {-IT Monitoring }\end{array}$ & $\begin{array}{l}\text {-Business and IT partnerships } \\
\text {-Business and IT shared learning }\end{array}$ \\
\hline \multicolumn{4}{|c|}{ Mechanisms } \\
\hline & & COORDINATION & $(+)$ \\
\hline
\end{tabular}

\subsection{Mapping SAMM's Management Practices into ITGAP Model}

Two models were used in order to develop the proposed framework, the ITG assessment process (ITGAP) model proposed by Peterson (2004) and the strategic maturity model (SAM) model proposed by Luftman (2000). The ITG assessment process (ITGAP) model aims to evaluate ITG effectiveness in terms of ITG capability, ITG complexity and IT value. The structure of this model presents two axes, horizontal and vertical. Horizontally, this model includes an arrangement of three ITG capabilities to evaluate the integration of IT decision-making processes. The assessment of ITG capabilities helps organizations to identify what capabilities are in place and guide how to enable mechanisms to consolidate an effective ITG architecture. Particularly, this research is only focused on the horizontal axe of this model and the structure of ITG capabilities.

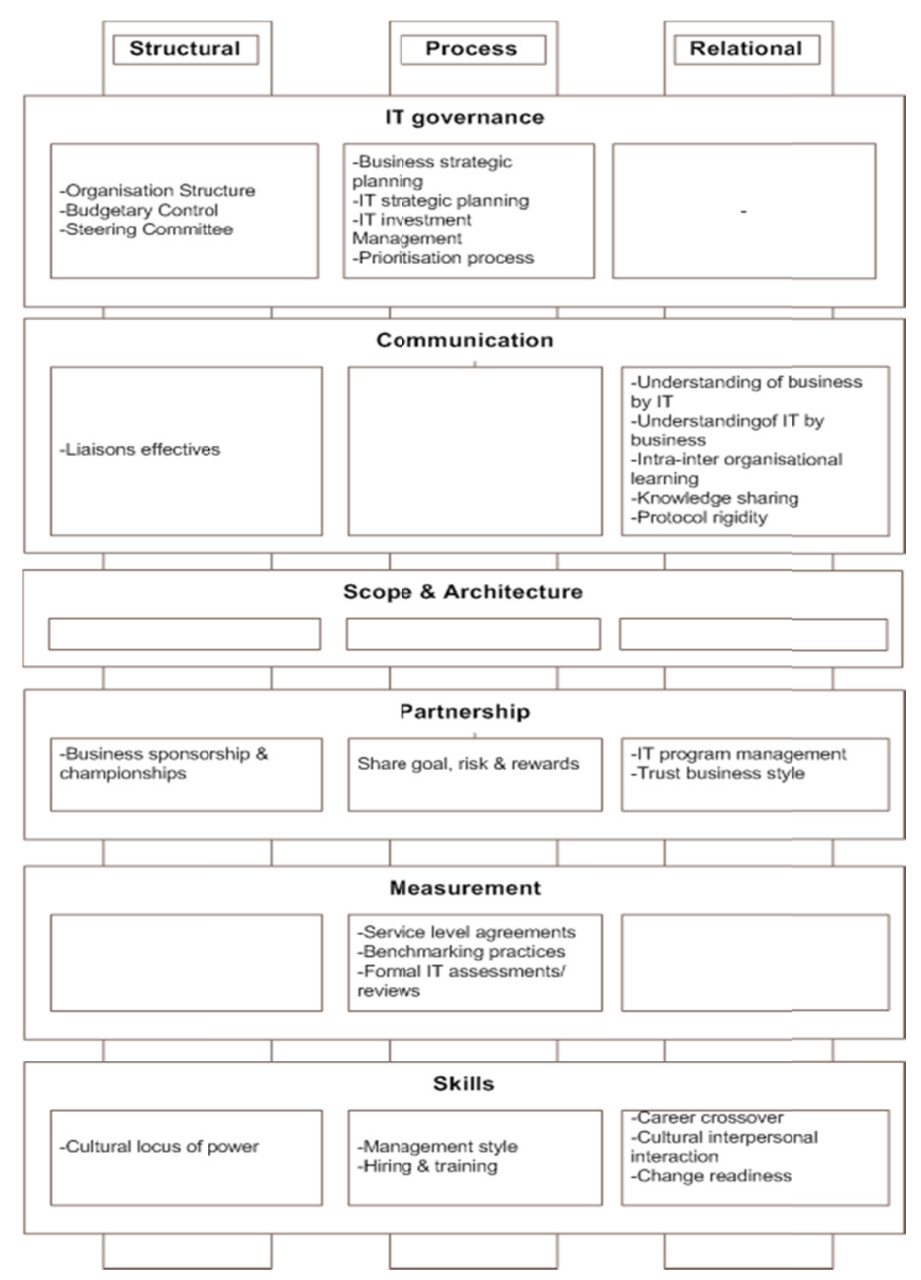

Figure 1. Categorization of IS/business alignment management practices in ITG capabilities 
The SAMM model was selected to provide IS/business alignment management practices for this study. The rationale to select this model was based on two main arguments. Firstly, existing IS/business alignment assessments are either theoretical conceptualizations or particular studies that cannot be applied generically in several organizations (Gutierrez, Orozco, Papazafeiropoulou, \& Serrano, 2008). Hence, SAMM, on the contrary, is a practical method for analyzing organizational maturity of IS/business alignment by means of ranking management practices within five levels of maturity [initial, committed process, established focused, improved and optimized process]. Each of these levels is subdivided into six factors [communication, value, governance, partnership, scope $\&$ architecture, and skills] and each factor is also subdivided in a set of management practices, also called attributes. SAMM has recently been tested and validated (Sledgianowski \& Luftman, 2005). Their findings show that the SAMM can be used as reliable diagnostic tool to improve the maturity levels of IS/business alignment. Gutierrez et al. (2009) also validates SAMM's reliability. The authors analyze the significance of its factors against organization size and indicate that the six factors are significant for either large, medium or small organizations. Secondly, the SAAM has been enriched from previous research and is still generating research interests. The SAMM is originally based on the strategic alignment model (SAM) but, in comparison to the latter, it covers additional factors, for instance organizational value creation.

The management practices proposed by SAMM were taken as sources of ITGAP mechanisms. In total 26 management practices were identified and categorized according the capabilities' structure in ITGAP. The selected management practices were categorized in three key mechanisms, process, relational and structure. To do this categorization, descriptions of each attribute (management practices) in SAMM as well as definitions of components in ITGAP were taken as the main reference. This categorization was used as a reference for the case study analysis presented in the following section (see Figure 1).

Since the ITG mechanisms can be elements of analysis in different IS/business alignment dimensions, it was decided to map ITG capabilities against different IS/business alignment dimensions. In practice, the implementation of ITG mechanisms might impact one or more organizational levels but also they might have been subject of analysis at different IS/business alignment dimensions. In this mapping, it was considered three sets of ITG capabilities [structure, process and relational] and four IS/business alignment dimensions [social, operational, informal structural and intellectual]. This mapping aimed to analyze the impact of different ITG capabilities at different IS/business alignment dimensions. The scope of each IS/business alignment dimension depicted in our mapping was based on definitions provided by Chan and Reich (2007) and Gutierrez et al. (2008). This mapping is also addressed the relationships between the three integration key mechanisms in order to indicate their management actions [coordination, collaboration and connection] and how they enable ITG integration. The final mapping is shown in figure 2.

\section{Qualitative Analysis: A Case Study}

A case study approach was selected as a method of study as this research is focused on the context of managerial actions and their making decisions processes. One case study was conducted as a pilot to identify relevant IS/business alignment management practices that can moderate the design of ITG architectures. The framework proposed in Figure 2 was applied on one the snack food business unit (BU) of a large leading international food and beverage company, hereafter called CompX in 2010. Some positions at top management provide share services to other business units also within the snack food sector. Traditionally, business units have been independent and autonomous, as management identifies noticeable differences in their business rationale. However, the implementation of share services for both business units have been the cause of structural and functional changes over the past years. Although data from two business units in the same family business could limit the findings of this research, this attempt had an objective to test and present initial results from the proposed framework. For further enhancements, additional data from other two large organizations will be integrated to enrich the results presented in this paper. 


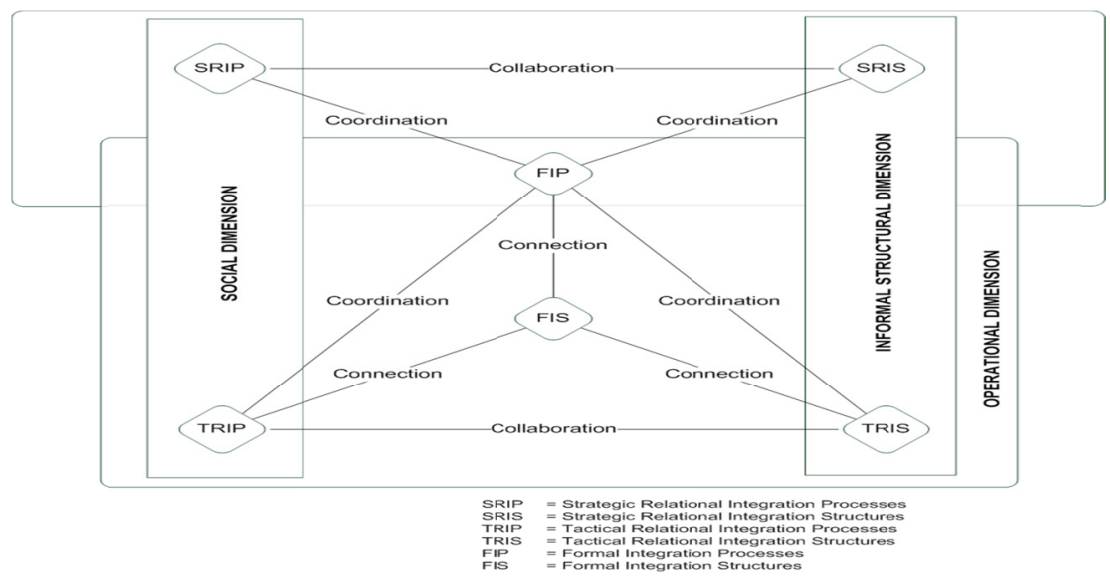

Figure 2. Mapping of integration strategies and tactics, and IS/Business alignment dimensions

Source: Adapted from Peterson (2004).

\subsection{Case Study}

CompX is headquartered in Mexico City and is a leader in the Mexican snack food market. CompX is part of an international business group in the sector of beverages and food but in Mexico CompX serves as umbrella to commercialize international as well as local snack brands. CompX is renowned for the quality, variety and flavors of its products. Locally, CompX controls around $80 \%$ of the Mexican snacks market and hold a respectable brand along their clients. Due to a recent organizational restructuration, some management positions at CompX share services with other business unit, hereafter called CompZ. CompZ is the largest manufacturer of cookies and market leader in Mexico. CompZ holds well-known brands and offers a wide variety of pastries, oats, cereals and cookies. Both business units have been facing several IT changes in the last four years. One of the biggest projects both business units are dealing with is the implementation of SAP in core business processes. This project has been a starting point to transform an organization traditionally functional into a new process-oriented organization. In addition, several structural changes have been taking in place over the past two years as consequence of a strategy based on higher productivity and cost-decreasing.

\subsection{Data Collection}

The methods to collect data included questionnaires and semi-structured interviews. Both sources were taken into account to perform the analysis. Although the combination of research methods in information systems research could be uncommon, a multi-method research design can bring noticeable advantages (Gable, 1994). In total, twenty face-to-face semi- structured interviews were conducted with a length of approximately one hour. All interviewed participants were at managerial levels and holding executive, senior, tactical and operational managerial positions (see Table 2). Executive positions included those participants that have strategic roles and hold either head or director positions at corporate level. Senior positions involved strategic roles that hold either director or head positions at business unit level. Tactical managers include participants in charge of tactical implementations such as intra-organizational or inter-organizational projects at business unit level. Operational managers grouped managerial positions closer to the execution of operational activities or implementation of subsets of strategic projects. In addition, a balanced representation between IT and business roles was considered (see Table 3).

Table 2. Number of samples of data collected

\begin{tabular}{lll}
\hline Organizational position & Data collection technique & \\
\hline & Semi-structured interviews & $\begin{array}{l}\text { Questionnaire } \\
\text { (IT project alignment maturity) }\end{array}$ \\
\hline Executive & 5 & \\
Senior Manager & 5 & 3 \\
Tactical Manager & 7 & 3 \\
Operational Manager & 3 & \\
\hline
\end{tabular}




\subsection{Method of Analysis}

Nvivo 8.0 was the main tool used in support of the overall qualitative research effort. Each interview was recorded and later transcribed. All transcripts were uploaded and saved into Nvivo as content sources. Each participant was the unit of analysis and a case node per participant was created. To map the content of each transcript against the constructors of the proposed framework, a node was created per each management practice depicted in Figure 1. These nodes were also arranged into coding hierarchies. To do so, a tree node structure was created to categorize process, structure and relational capabilities as indicated by ITGAP. The content analysis was performed coding each interview according the defined nodes and identifying relationships between them. Questionnaires were also applied to managers in charge of delivering high IT-dependant projects. To analyze this data, an adapted version of the strategic alignment maturity model to assess strategic IT projects was used (Gutierrez et al., 2008). Two strategic projects were assessed and six participants involved in these projects were asked to answer the questionnaire.

Table 3. Role of interviewed organizational positions

\begin{tabular}{ll}
\hline Organizational role & Number of interviewed people \\
\hline IT & 5 \\
Business & 13 \\
Both & 2 \\
\hline
\end{tabular}

The analysis was focused on the identification of the relevance of each management practice along different making-decision processes and its impact in the IT/business value perceived. The results from the questionnaires helped to corroborate the results from the interviews and provided additional insights. When potential new constructors were identified, free nodes were created. However, these new nodes only helped to outline characteristics, similarities and differences between both business units. It was also performed a checking process to ensure that possible missing content was not included in the final codification. The identification of relevant coded nodes was performed assessing the number of coding references and using query functionalities in Nvivo. The queries were defined and executed taking into account the organizational role and positions of participants. For instance, content codification from executive and senior managers was relevant to identify strategic relational integration processes, strategic relational integration structures and formal integration processes since these capabilities influence the intellectual or strategic dimension of IS/business alignment. Similarly, content codification from tactical and operational managers was relevant to identify formal integration process, formal integration structures, tactical relational integration process and tactical relational integration structures, as these capabilities influence the operational dimension of IS/business alignment.

\subsection{Analysis and Discussion}

Formal capabilities [structural and process] appear as core references in order to improve organizational integration. Particularly, the restructuration or redesign of former organizational structures is perceived as applicable attempts to achieve higher organizational integration. However, the implementation of new processes, their redesign or changes are perceived as bureaucratic activities that limit organizational flexibility and responsiveness. Similar results indicate that organizational structures tend to implement easier relational capabilities in comparison to process capabilities (De Haes \& Van Grembergen, 2009).

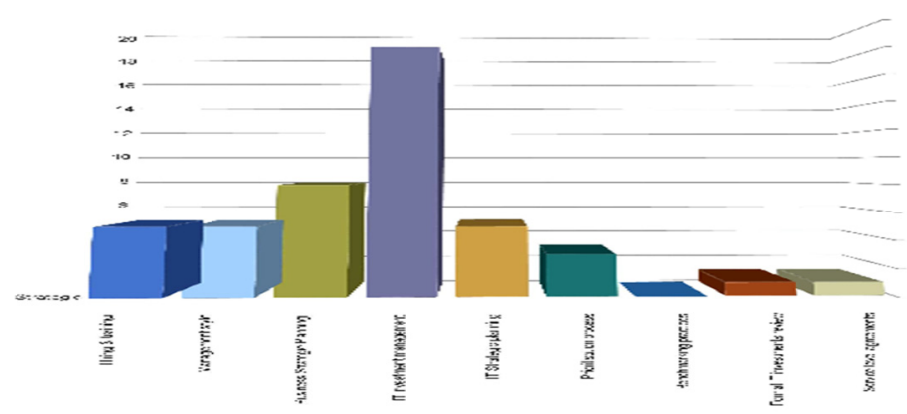

Figure 3. Formal integration process codification at strategic level 


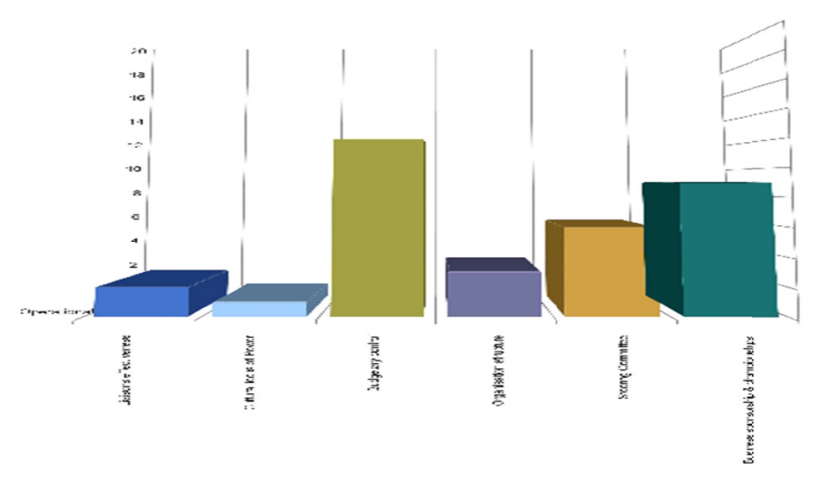

Figure 4. Formal integration structures codification at operational level

Formal integration processes undertake an angular place within our proposed framework. Three formal processes, IT investment management, IT project prioritization and business planning, influence significantly the design of ITG architectures. Commonly, these three processes are fundamental pieces along the strategic IS planning. Strategic IS planning reconciles bottom-up and top-down approaches during the strategy formulation (Benbya \& McKelvey, 2006) and influences the organization at strategic, tactical and operational levels as long as uniform and consistent decisions towards IT projects and investments are made (Peak, Guynes, \& Kroon, 2005). However, literature in IS/business alignment has rarely shown studies that integrate strategic and operational dimensions (Gutierrez, Orozco, \& Serrano, 2009). Conversely, business and IS planning process consists of a multilevel scope that includes the implementation of both operative and strategic management practices in order to be effective (Grant, Hackney, \& Edgar, 2009). The business planning process was identified relevant for strategic level positions whereas the IT investment management process for strategic, tactical and operational positions (see Figure 3). At operational level, the IT project prioritization process was also diagnosed with pertinent attention.

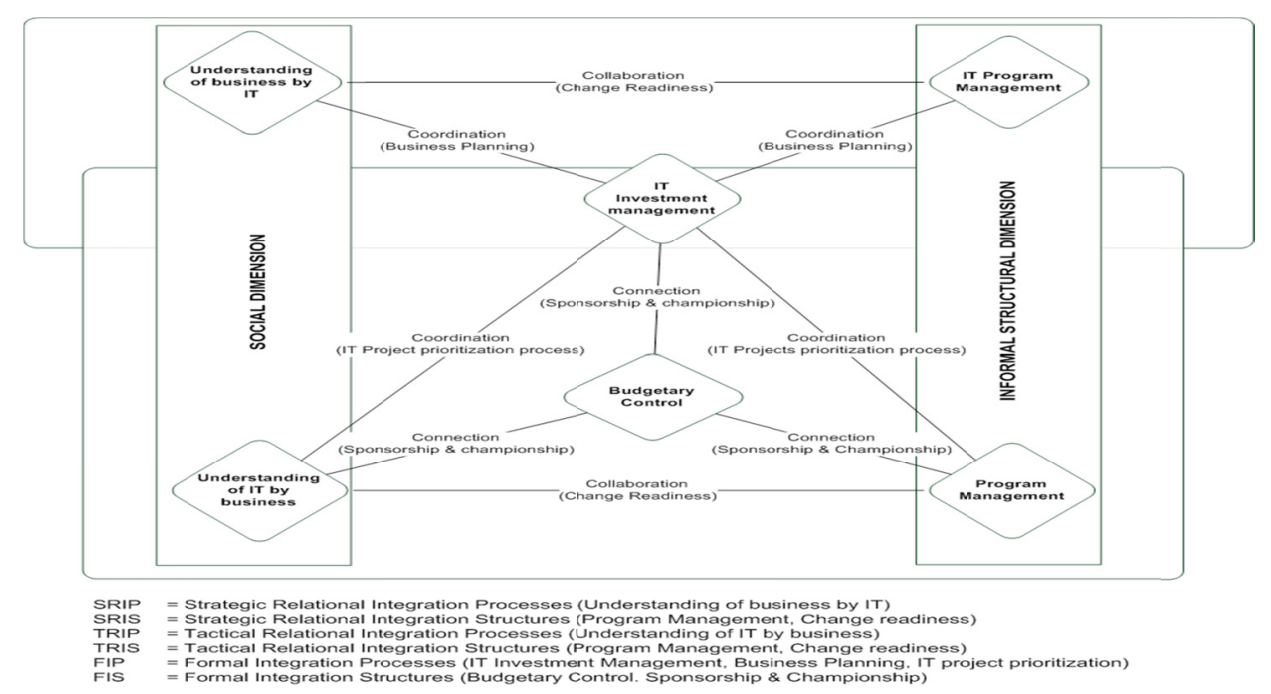

Figure 5. Integration of relevant IS/Business alignment management practices for the design of ITG architectures

Luftman (2000) does not suggest any relationship between attributes since all are equally relevant in order to assess IS/business alignment. However, some attributes can be consequences or antecedents of others. For instance, both business planning and IT project prioritization processes can be categorized as sub-process in the stages of the IT investment management process. In the proposed framework we address these relationships. Both business planning and IT project prioritization process have been depicted as relationships since they can be preceding sub-process of IT investment management. For instance, a formal IT investment management process can be structured in five key stages (idea generation, business case generation, investment selection, 
project implementation and achieving benefit) (Sherer, 2007). All results discussed in this section are presented and mapped in the proposed framework in Figure 5.

\section{Discussions and Conclusions}

The results from this research indicate that at operational and tactical levels, improving the coordination of the IT investment management process and enabling structures that strengthen the connection of budgetary controls will impact the integration of additional formal capabilities and consequently moderate positively the process of IS/business alignment and enable mechanisms to design effective ITG architectures (see Figure 4). For example, between strategic and operational levels, promoting program management practices would influence collaboration towards a unified understanding of IT and business knowledge. From a practitioner's point of view, these results suggest that management should concentrate and put special emphasis in control mechanisms to support and monitor the IT investment management process and consolidate it by means of improved structural costing schemas. Specially, there is a need to permeate balanced practices between stakeholders. In our case study, several issues related to IT investments were caused by the lack of standardize procedures since the diversity of informal practices were caused of conflicts and misalignment. At strategic level, positions found that the business understanding of IT affects their strategic relational and process integration capabilities. Conversely, operational positions evidenced that the IT understanding of business influences their tactical relational, process and structure capabilities.

\section{References}

Abbasi, M. S., Tarhini, A., Hassouna, M., \& Shah, F. (2015). Social, Organizational, Demography and Individuals' Technology Acceptance Behaviour: A Conceptual Model. European Scientific Journal, 11(8).

Alenezi, H., Tarhini, A., \& Masa'deh, R. (2015). Exploring the Relationship between Information Quality and e-Government Benefits: A Literature Review. International Review of Social Science and Humanities, 9(1).

Avison, D., Jones, J., Powell, P., \& Wilson, D. (2004). Using and validating the strategic alignment model. The Journal of Strategic Information Systems, 13(3), 223-246. http://dx.doi.org/10.1016/j.jsis.2004.08.002

Balocco, R., Ciappini, A., \& Rangone, A. (2013). ICT governance: A reference framework. Information Systems Management, 30(2), 150-167. http://dx.doi.org/10.1080/10580530.2013.773808

Beimborn, D., Schlosser, F., \& Weitzel, T. (2009). Proposing a theoretical model for IT governance and IT business alignment. System Sciences, 2009. HICSS'09. 42nd Hawaii International Conference on Information Systems (pp. 1-11). IEEE.

Benbya, H., \& McKelvey, B. (2006). Using coevolutionary and complexity theories to improve IS alignment: A multi-level approach. Journal of Information Technology, 21(4), 284-298. http://dx.doi.org/10.1057/palgrave.jit.2000080

Broadbent, M., \& Weill, P. (1993). Improving business and information strategy alignment: Learning from the banking industry. IBM Systems Journal, 32(1), 162-179. http://dx.doi.org/10.1147/sj.321.0162

Buchwald, A., Urbach, N., \& Ahlemann, F. (2014). Business value through controlled IT: Toward an integrated model of IT governance success and its impact. Journal of Information Technology, 29(2), 128-147. http://dx.doi.org/10.1057/jit.2014.3

Chan, Y. E. (2001). Information systems strategy, structure and alignment. Strategic Information Technology: Opportunities for competitive advantage (1st ed.). Hershey, PA: Idea Group Publishing.

Chan, Y. E. (2002). Why haven't we mastered alignment? The importance of the informal organization structure. MIS Quarterly executive, 1, 97-112.

Chan, Y. E., \& Reich, B. H. (2007). IT alignment: what have we learned? Journal of Information Technology, 22(4), 297-315. http://dx.doi.org/10.1057/palgrave.jit.2000109

Chan, Y. E., Sabherwal, R., \& Thatcher, J. B. (2006). Antecedents and outcomes of strategic IS alignment: An empirical investigation. Engineering Management, IEEE Transactions on Engineering Management, 53(1), 27-47. http://dx.doi.org/10.1109/TEM.2005.861804

Chaudhuri, A. (2011). Enabling Effective IT Governance: Leveraging ISO/IEC 38500: 2008 and COBIT to Achieve Business-IT Alignment. EDPACS, 44(2), 1-18. http://dx.doi.org/10.1080/07366981.2011.599278

Chiang, I. R., \& Nunez, M. A. (2013). Strategic alignment and value maximization for IT project portfolios. Information Technology and Management, 14(2), 143-157. http://dx.doi.org/10.1007/s10799-012-0126-9 
Ciborra, C. U. (1997). De profundis? Deconstructing the concept of strategic alignment. Scandinavian Journal of Information Systems, 9(1), 67-82.

Coltman, T., Sharma, R., \& Tallon, P. (2013) Strategic IT alignment: Twenty five years on. Journal of Information Technology, 28(2), 143-157. http://dx.doi.org/10.1016/S0963-8687(02)00007-0

Cragg, P., King, M., \& Hussin, H. (2002). IT alignment and firm performance in small manufacturing firms. The Journal of Strategic Information Systems, 11(2), 109-132.

Curry, M., Marshall, B., \& Kawalek, P. (2014). IT artifact bias: How exogenous predilections influence organizational information system paradigms. International Journal of Information Management, 34(4), 427-436. http://dx.doi.org/10.1016/j.ijinfomgt.2014.02.005

De Haes, S., \& Van Grembergen, W. (2010). Analysing the impact of enterprise governance of IT practices on business performance. International Journal of IT/Business Alignment and Governance (IJITBAG), 1, 14-38. http://dx.doi.org/10.4018/jitbag.2010120402

De Haes, S., \& Van Grembergen, W. (2009). An exploratory study into IT governance implementations and its impact on business/IT alignment. Information Systems Management, 26(2), 123-137. http://dx.doi.org/10.1080/10580530902794786

Gable, G. G. (1994). Integrating case study and survey research methods: An example in information systems. European Journal of Information Systems, 3(2), 112-126. http://dx.doi.org/10.1057/ejis.1994.12

Grant, K., Hackney, R., \& Edgar, D. (2009). Strategic information systems management. Delmar Learning.

Gutierrez, A., Mylonadis, C., Orozco, J., \& Serrano, A. (2008). Business-IS alignment: Assessment process to align IT projects with business strategy. AMCIS 2008 Proceedings. Toronto, ON, Canada, Paper 290.

Gutierrez, A., Orozco, J., \& Serrano, A. (2006). Using tactical and operational factors to assess Strategic Alignment: An SME study. Proceeding in the European and Mediterranean Conference on Information Systems. Alicante, Spain, 2005.

Gutierrez, A., Orozco, J., \& Serrano, A. (2009). Factors affecting IT and business alignment: A comparative study in SMEs and large organisations. Journal of Enterprise Information Management, 22(1/2), 197-211. http://dx.doi.org/10.1108/17410390910932830

Gutierrez, A., Orozco, J., Papazafeiropoulou, A., \& Serrano, A. (2008). Developing a taxonomy for the understanding of business and IT alignment paradigms and tools. Proceeding in the 16th European Conference on Information Systems (pp. 2472-2483). Galway, Ireland.

Henderson, J. C., \& Venkatraman, N. (1993). Strategic alignment: Leveraging information technology for transforming organizations. IBM Systems Journal, 32(1), 4-16. http://dx.doi.org/10.1147/sj.382.0472

Hirschheim, R., \& Sabherwal, R. (2001). Detours in the path toward strategic information systems alignment. California Management Review, 44(1), 87-108. http://dx.doi.org/10.2307/41166112

ISO/IEC 38500. (2014). Corporate Governance of Information Technology. Retrieved from http://www.itgi.com

Kearns, G. S., \& Lederer, A. L. (2003). A resource-based view of strategic IT alignment: How knowledge sharing creates competitive advantage. Decision Sciences, 34(1), 1-29. http://dx.doi.org/10.1111/1540-5915.02289

Kearns, G., \& Lederer, A. L. (2000). The effect of strategic alignment on the use of IS-based resources for competitive advantage. The Journal of Strategic Information Systems, 9(4), 265-293. http://dx.doi.org/10.1016/S0963-8687(00)00049-4

Luftman, J. (2004). Assessing business-IT alignment maturity. Strategies for Information Technology Governance, 4(1), 99-119. http://dx.doi.org/10.4018/978-1-59140-140-7.ch004

Masa'deh, R., \& Kuk, G. (2009). Antecedents and intermediaries between strategic alignment and firm performance. Proceedings of the 2009 Conference of the Academy of Management Annual Meeting (AOM).

Masa'deh, R., \& Shannak, R. (2012). Intermediary effects of knowledge management strategy and learning orientation on strategic alignment and firm performance. Research Journal of International Studies, 24, $112-128$.

Masa'deh, R., Maqableh, M., \& Karajeh, H. (2014). IT-business strategic alignment: The role of mobile technology usage. Proceedings of the 23rd IBIMA Conference on Vision 2020: Sustainable Growth, Economic Development, and Global Competitiveness. Valencia, Spain. 
Melville, N., Kraemer, K., \& Gurbaxani, V. (2004). Review: Information technology and organizational performance: An integrative model of IT business value. MIS Quarterly, 28(2), 283-322.

Papp, R., \& Luftman, J. (1995) Business and IT strategic alignment: New perspectives and assessments. Proceedings of the Association for Information Systems, Inaugural Americas Conference on Information Systems (pp. 25-27). McGraw-Hill.

Peak, D., Guynes, C. S., \& Kroon, V. (2005). Information technology alignment planning-A case study. Information \& Management, 42(5), 635-649. http://dx.doi.org/10.1016/j.im.2004.02.009

Peterson, R. (2004). Crafting information technology governance. Information Systems Management, 21(4), 7-22. http://dx.doi.org/10.1201/1078/44705.21.4.20040901/84183.2

Peterson, R. R., O'Callaghan, R., \& Ribbers, P. (2000) Information technology governance by design: Investigating hybrid configurations and integration mechanisms. Proceedings of the Twenty First International Conference on Information Systems (pp. 435-452). Brisbane, Australia.

Pyburn, P. J. (1983). Linking the MIS plan with corporate strategy: An exploratory study. MIS Quarterly, 7(2), 1-14. http://dx.doi.org/10.2307/248909

Reich, B. H., \& Benbasat, I. (2000). Factors that influence the social dimension of alignment between business and information technology objectives. MIS Quarterly, 24, 81-113. http://dx.doi.org/10.2307/3250980

Schlosser, F., Wagner, H. T., Beimborn, D., \& Weitzel, T. (2010). The Role of Internal Business/IT Alignment and IT Governance for Service Quality in IT Outsourcing Arrangements. System Sciences (HICSS), 2010 43rd Hawaii International Conference on (pp. 1-10). IEEE.

Shannak, R., Masa'deh, R., Obeidat, B., \& Almajali, D. (2010). Information technology investments: A literature review. The 14th IBIMA Conference on Global Business Transformation through Innovation and Knowledge Management: An Academic Perspective. Istanbul-Turkey, 23rd-24th June (pp. 1356-1368).

Sherer, S. A. (2007). Comparative study of IT investment management processes in US and Portugal. Journal of Global Information Management (JGIM), 15(3), 43-68. http://dx.doi.org/10.4018/jgim.2007070103

Simonsson, M., Johnson, P., \& Ekstedt, M. (2010). The effect of IT governance maturity on IT governance $\begin{array}{lllll}\text { performance. } & \text { Information } & \text { Systems } & \text { Management, } & \text { 27(1), }\end{array}$ http://dx.doi.org/10.1080/10580530903455106

Siurdyban, A. (2014). Understanding the IT/business Partnership: A Business Process Perspective. Information Systems Frontiers, 16(5), 909-922. http://dx.doi.org/10.1007/s10796-012-9388-3

Sledgianowski, D., \& Luftman, J. (2005). IT-business strategic alignment maturity: A case study. Journal of Cases on Information Technology (JCIT), 7(2), 102-120. http://dx.doi.org/10.4018/jcit.2005040107

Smaczny, T. (2001). Is an alignment between business and information technology the appropriate paradigm to manage IT in today's organisations? Management Decision, 39(10), 797-802. http://dx.doi.org/10.1108/EUM0000000006521

Tallon, P. P., Ramirez, R., \& Short, J. E. (2013). The information artifact in IT governance: Toward a theory of information governance. Journal of Management Information Systems, 30(3), 141-177. http://dx.doi.org/10.2753/MIS0742-1222300306

Tarhini, A., Ammar, H., Tarhini, T., \& Masa'deh, R. (2015). Analysis of the Critical Success Factors for Enterprise Resource Planning Implementation from Stakeholders' perspective: A Systematic Review. International Business Research, 8(4), 25-40. http://dx.doi.org/1.05539/ibr.v8n4p25

Tarhini, A., Hassouna, M., Abbasi, M. S., \& Orozco, J. (2015). Towards the Acceptance of RSS to Support Learning: An empirical study to validate the Technology Acceptance Model in Lebanon. Electronic Journal of e-Learning, 13(1), 30-41.

Tarhini, A., Scott, M., Sharma, K. S., \& Abbasi, M. S. (2015). Differences in Intention to Use Educational RSS Feeds Between Lebanese and British students: A Multi-Group Analysis Based on the Technology Acceptance Model. Electronic Journal of E-Learning, 13(1), 14-29.

Tarhini, A., Teo, T., \& Tarhini, T. (2015b). A cross-cultural validity of the E-learning Acceptance Measure (ElAM) in Lebanon and England: A Confirmatory Factor Analysis. Education and Information Technologies. http://dx.doi.org/10.1007/s10639-015-9381-9

Teo, T. S., \& King, W. R. (1996). Assessing the impact of integrating business planning and IS planning. 
Information \& Management, 30(6), 309-321. http://dx.doi.org/10.1016/S0378-7206(96)01076-2

Thompson, S., Ekman, P., Selby, D., \& Whitaker, J. (2014). A model to support IT infrastructure planning and the allocation of IT governance authority. Decision Support Systems, 59, 108-118. http://dx.doi.org/10.1016/j.dss.2013.10.010

Tiwana, A. (2012). Novelty-knowledge alignment: A theory of design convergence in systems development. Journal of Management Information Systems, 29(1), 15-52. http://dx.doi.org/10.2753/MIS0742-1222290101

Wagner, H. T. (2014). Evolvement of business-IT alignment over time: A situated change perspective. Proceedings of the 47th Annual Hawaii International Conference on System Sciences (pp. 4366-4375).

Wagner, H. T., \& Weitzel, T. (2012). How to achieve operational business-IT alignment: Insights from a global aerospace firm. MIS Quarterly Executive, 11(1), 25-35.

Wagner, H. T., Beimborn, D., \& Weitzel, T. (2014). How social capital among information technology and business units drives operational alignment and IT business value. Journal of Management Information Systems, 31(1), 241-272. http://dx.doi.org/10.2753/MIS0742-1222310110

Walter, J., Kellermanns, F., \& Floyd, S. (2013). Strategic alignment: A missing link in the relationship between strategic consensus and organizational performance. Strategic Organization, 11(3), 304-328. http://dx.doi.org/10.1177/1476127013481155

Weill, P., \& Ross, J. W. (2004). IT governance: How top performers manage IT decision rights for superior results. Harvard Business Press.

Wraikat, M. (2012). Information technology governance role in enhancing performance: A case study on Jordan public sector. Proceedings of the World Congress on Engineering and Computer Science. San Francisco, CA.

Yayla, A. A., \& Hu, Q. (2012). The impact of IT-business strategic alignment on firm performance in a developing country setting: Exploring moderating roles of environmental uncertainty and strategic orientation. European Journal of Information Systems, 21(4), 373-387. http://dx.doi.org/10.1057/ejis.2011.52

Zolper, K., Beimborn, D., \& Weitzel, T. (2014). The effect of social network structures at the business/IT interface on IT application change effectiveness. Journal of Information Technology, 29(2), 148-169. http://dx.doi.org/10.1057/jit.2014.6

\section{Copyrights}

Copyright for this article is retained by the author(s), with first publication rights granted to the journal.

This is an open-access article distributed under the terms and conditions of the Creative Commons Attribution license (http://creativecommons.org/licenses/by/3.0/). 